\title{
APPLICATION PRACTICE OF TRAVAUX \\ PREPARATORIES BY THE UNIVERSAL COURT \\ OF JUSTICE FOR THE DISTRIBUTION \\ OF THE MARINE BORDERS OF STATES
}

\section{Karvatska Svitlana ${ }^{1}$}

DOI: https://doi.org/10.30525/978-9934-571-78-7_35

Abstract. The subject of the study of the proposed article is the practice of using travaux preparatoires as additional materials by the ICJ. Empirical and practical approaches have been used to study the main issues, as well as analytical, hermeneutic, comparative-legal, logical, synthetic and statistical methods. The purpose of this study is to identify the specific features that are characteristic of the international treaties interpretation implemented by the International Court of Justice. As a result of the study, a number of conclusions were formulated. Analyzing the practice of applying travaux preparatoires in various international courts, we can state that the interpretation carried out by the International Court of Justice has its own peculiarities. The documents used as travaux preparatoires are usually official, first in writing, and secondly, available and known to all negotiators. They relate to the fixing of the negotiation, development and discussion during the conclusion of the treaty, statements, reservations, etc. The main source for interpretation of treaties is the Vienna Convention, which contains the general rule of interpretation for all founding treaties of international organizations, but the UN International Court of Justice sometimes practices the interpretation of «certain types of treaties», which are subject to a special approach. The UN ICJ uses different rules of interpretation, which is an extremely complex process and requires consideration of different circumstances and the use of additional travaux preparatoires for the purpose of clarifying the intentions of the parties to the dispute and settling it regarding the text, context, purpose and object of the treaty, in accordance with the general rules of interpretation, fixed in art. 31 of the

\footnotetext{
${ }^{1}$ Ph.D. in Law, Doctoral Candidate at the Institute of International Relations,

Taras Shevchenko National University of Kyiv, Ukraine;

Associate Professor of Department of Human Rights Law Faculty,

Yuriy Fedkovych Chernivtsi National University, Ukraine

(C) Karvatska Svitlana
} 


\section{Karvatska Svitlana}

Vienna Convention on the Law of Treaties, 1969. The practice of travaux preparatoires requires, in the main, a combination of several interpretive approaches and extraordinary accuracy in the analysis and in the explanation of additional materials to the texts of treaties. The appeal to the travaux preparatoires, the by-product of which is the subjectivity of this practice, does not always find approval among the participants in the discussion, even among the judges of the ICJ who adhere to the rules of interpretation of Art. 31. However, the more time it takes to adopt the most of the founding treaties of international organizations and apply the conventions by the Court, the greater is the necessity to turn to the evolutionary approach of interpretation and to find the true understanding of the provisions of the treaties by its participants with the help of travaux preparatoires, the use of which is not arbitrary in accordance with the requirements of the Vienna Convention.

\section{Introduction}

It shouldn't be forgotten when the letter of the law is obscure, ambiguous, or incomplete, denying the judge the power to search for the ratio legis may be considered to be a denial of justice. But where can we find the ratio legis, if not in the travaux préparatoires? The identification of the travaux préparatoires theory requires, first of all, a definition of that term. This, in turn, requires an overview of the legislative process including the informal ministerial drafting phase and the formal phase involving the debates before the two chambers of Parliament. The true spirit of the law can and should, be established by documents that are accessible to the public. The principle of secrecy overshadowing parts of the legislative process presents a considerable obstacle. A comprehensive investigation into the legislative history of a statute, including its historical context, takes more time than busy practitioners often have. None the less, the travaux préparatoires have established themselves as an important tool for interpretation when courts have to determine the conformity of a national statute with an international Treaty, or with the Constitution.

The use of travaux preparatoires is practiced in various international courts both at the global and regional levels, respectively. It is also known about their use in US courts. The most authoritative is their use as additional materials by the UN International Court of Justice, because in this case they become the source of law. 
Travaux preparatoires or actes preparatoires, borrowed from French («preparatory work»), is used in English in international law in several ways: «history of negotiations», «history of development», «history of legislation» (as synonymous with the history of treaty ratification), but generally it's referred to all the documents (memorandums, protocols of conferences and draft contracts used in negotiations, etc.) for the purpose of interpretation of the treaty [16].

Synonymous phrases are also "negotiating history" or "drafting history". It is not correct to use the phrase "legislative history" as a synonym. While they bear similarities, treaty interpretation differs significantly from statutory construction). As well, there is another use for the phrase "legislative history" - as a synonym for the ratification, made in order to give effect to the treaty in the national law, history of an international treaty.

This includes various materials: preliminary draft agreements, correspondence of the negotiators, records of their comments to the plenary committee, reports of committees, reports of speakers, sometimes public statements of ex-officio negotiators, state officials, and materials recorded as «authentic interpretation».

Travaux preparatoires of a statute or treaty are usually recorded. That's why it can be further used in order to interpret provisions or the treaty as a whole. This is a secondary form of interpretation and is used to clarify the intent of the makers of the statute or treaty. Travaux preparatoires are of particular importance to the courts which use them in order to reach a final decision in settling international disputes.

Judges, in interpreting legislative norms or establishing jurisprudence in their application, often use legislative preparatory work as a means of illumination to understand the will of the legislator. The travaux préparatoires are often available on special websites created for a specific treaty (such as the Rome Statue) or on the United Nations website. The most well-known ones are associated with the Genocide Convention.

Among the scholars who are pay attention to the problem of using travaux preparatoires in the work of international courts, we can single out such as Marco Benatar, Marc J. Bossuyt, Matthew C.R. Craven, Sharon Detrick, Gerald Fitzmaurice, Erik Frank, Hersh Lauterpacht, Julia Movchan, Francisco Lertora Pinto, Jonathan Pratter, Dietrich Rauschning, Lars A. Rehof, Martin Ris, William A. Schabas, Paul Weis, Ralf Günter Wetzel, Peter Quayle. However, so far, there is a lack of general, systematic and complex studies on the use of travaux preparatoires. 


\section{Karvatska Svitlana}

\section{Basic Conceptual Approaches to Interpretation}

Analyzing the practice of applying travaux preparatoires in various international courts, we can state that the interpretation carried out by the International Court of Justice has its own peculiarities

The International Court of Justice uses different rules of interpretation, which is a highly difficult process in need of taking different circumstances and the use of additional travaux preparatoires into account in order to establish the Court's jurisdiction in order to clarify true intensions of dispute`s parties and dispute's solving concerning the text, the context, the aim and the object of the treaty according to the general rule of interpretation, stated in the 31 article of the Vienna Convention on the Law of Treaties. In this process not only the texts of articles and their projects are used but also official letters, maps, documents of ratification, etc.

The documents used as travaux preparatoires are usually official, first in writing, and secondly, available and known to all negotiators. They relate to the fixing of the negotiation, development and discussion during the conclusion of the treaty, statements, reservations, etc. Moreover, this process is rather long, for several years, «with thorough preparation and deliberation» [16]. They are considered and even taken into account not only during the conclusion of the treaty, but also when interpreting the contracts, and therefore the importance of such materials is difficult to overestimate.

However, researchers face incredible difficulty in finding them, for the most part they are not published, or they are published on the websites of international organizations, they are often not available to the general public or confidential (like most of the Council of Europe agreements), and when published in collections, it is often extremely difficult to finding the right document among thousands of preparatory materials. For example, more than 700 cases of travaux preparatoires to the Universal Declaration of Human Rights for the period from year 1946 from the beginning of the work of the Commission on Human Rights («nuclear») tontil its final adoption by the UNGA on December 10, 1948 were posted on more than 3,100 pages [20].

It is clear that these materials are used in the future as an additional means of interpretation when the value of the treaty is ambiguous or unclear, or leads to a result that is absurd or unreasonable in accordance with Art. 32 of the Vienna Convention on the Law of Treaties (1969) [1].

However, as William A. Schabas rightly points out, in the case of the Universal Declaration of Human Rights, the Vienna Convention does not 
apply because it is not a treaty, but it is similar to the treaty and there is no reason to apply a different approach to the interpretation of the Declaration from the one used for the treaty [20].

Well-known are the collections of travaux preparatoires materials for the Convention for the Protection of Human Rights and Fundamental Freedoms (1951), the Refugee Convention (1951) [24], the International Covenant on Civil and Political Rights (1966) [3], the International Covenant on Economic, Social, and Cultural Rights (1966) [7], Vienna Convention on the Law of Treaties (1969), [7] the United Nations Convention on the Elimination of all Forms of Discrimination Against Women (1979) [18], the United Nations Convention on the Rights of the Child (1989 p.) [9]. However, most of the materials are at the best on the websites of organizations, or not available for study.

Of course, the main source for interpretation of treaties is the Vienna Convention, which contains the general rule of interpretation for all founding treaties of international organizations, but the UN International Court of Justice sometimes practices the interpretation of «certain types of treaties», which are subject to a special approach, using advisory opinions that contain a direct answer to a matter of interpretation, or uses conclusions in which the matter of interpretation are touched only in passing, is «accidental in relation to the subject of the dispute on a treaty».

Peter Quayle singled out nine interpretative proposals used by the court: 1) a sufficiently clear text is convincing; 2) the text cannot be canceled; 3) travaux preparatoires working papers do not provide auxiliary interpretation; 4) consistent practice excludes intellectual interpretation; 5) to be consistent practice should not be unanimous; 6) consistent institutional practice is crucial; 7) the goal may compliment, but cannot contradict the practice; 8) practice is an interpretation that is not rejected institutionally; 9) interpretation may not be free of charge [17]. Peter Quayle contends that certain deviations from the provisions of the Convention by the Court allow the Court to apply a more efficient and effective approach to the interpretation of constituent documents and to make the institutional practice particularly popular [17].

Scientists have not come to a general agreement on the main approaches (schools) of interpretation used by the UN, but they are generally unanimous about identifying these three: intents, textual and teleological approaches, and sometimes point out the New Haven School [19] and the need for an evolutionary interpretation in the light of new living conditions. 


\section{Karvatska Svitlana}

In cases where the Court referred to the use of travaux preparatoires, the textual approach was mostly used, and sometimes intentions, when it was necessary to follow the behavior of the parties before and after the conclusion of the treaty, historical aspects, and to find out the true intentions regarding the goals and objectives of the parties.

\section{Textual Approach to the application of travaux preparatoires}

The textual approach to the application of travaux preparatoires has been used by the UN International Court of Justice and in the case (Romania v. Ukraine) (2008) [13] regarding the establishment of a single maritime border between the two states in the Black Sea and the delineation of the continental shelf and the exclusive economic zones belonging to them. The court has applied the previously developed three-step approach to maritime delimitation, namely:

1. Setting a time line of uniformity.

2. Considering the factors that influence the overall correction and the correction of the line. In particular, the Court has identified and analyzed the following factors:

1) possible disproportion between the lengths of coastal strips;

2) the closed nature of the Black Sea and the delineation already made in the region;

3) the presence of the Snake Island in the area of delimitation. The behavior of the Parties (oil and gas concessions, fishing activities and naval patrols).

3. Confirmation that the line adjusted this way will not lead to an unfair result by comparing the ratio of coastal lengths with the length of the corresponding marine areas. It was at the first step, during the establishment of the line of uniformity, when it was necessary to select the appropriate bases for the line (on Romanian side - the Sakalin peninsula and Sulin Dam, on Ukrainian side - Tsyganka Island and Cape Tarkhankut), the Court appealed to travaux preparatoires to justify the choice of Sulin Dam as a point.

The court considered the possibility of characterizing the nature of the Sulin Dam as a «port facility» and «an integral part of the port system», since such a definition is not included in the Convention on the territorial sea and adjacent zone of April 29, 1958 [6]. That's why it used travaux preparatoires to Article 8 of the Convention that deals with the distinction between dyke and port functions and noted that the concept of a dam is 
no longer used by international bodies, but refers mostly to the pier (Article 10) [para 134]. The court appealed to the expert's conclusions, who at the conference in 1958 argued that the port facilities, the piers in particular, are part of the continental territory [21].

The International Law Commission in a report sent to the UN General Assembly expressed doubts about the possibility of applying Art. 8 in case if the pier is too long (protrudes into the sea for several kilometers), however, it has not determined the conditions/limits for which the dam, pier or object cease to be «an integral part of the port system». Therefore, the Court applied an individual approach to the solution of this case, since Art. 11 and travaux preparatoires «do not exclude the possibility of a limited interpretation of the concept of port facilities in order to prevent or simplify the concept of excessive length defined by the ILC» [para 134], and therefore it can also be applied to the case of delimitation of zones that extending territorial waters.

The court stressed that, since the case had an international dimension, it relied on the choice of ascending points by both parties, and the choice of ascending points by Ukraine was not challenged [para 135]. As we see, the UN ICJ used the classic for travaux preparatoires method of textual interpretation of Art. 8 of the Geneva Convention on Territorial Sea and Contiguous Zone. However, if, for the most part, the subjects of interpretation seek to clarify the purpose and object of the contract, then in this case it was about clarifying the «agreed definitions».

The Court notes, however, that the functions of a dyke are different from those of a port: in this case, the Sulina dyke may be useful for protecting navigation destined for the mouth of the Danube and for the ports located there. The difference between a port and a dyke that stretches toward the sea was previously discussed in the travaux préparatoires of Article 8 of the Geneva Convention on the Territorial Sea and Contiguous Zone.

In 1954, the Special Rapporteur of the ILC noted that "dykes used to protect the coast are a separate problem and do not fall under Article 9 (ports) and Article 10 (roadsteads)". Afterwards, the concept of a "dyke" was no longer used, and reference was made to "jetties" which serve to protect coasts from the sea. The first sentence of Article 11 of UNCLOS, with the exception of one minor change in the wording, corresponds to that of Article 8 of the Convention on the Territorial Sea and Contiguous Zone. The second sentence, which suggests that "permanent harbour works" 


\section{Karvatska Svitlana}

does not include "off-shore installations and artificial islands", is new. The expert at the 1958 Conference stated that "harbour works such as jetties [are considered] as part of ... land territory".

It should be noted, however, that the ILC included the following comment in its report to the General Assembly: "(3) If such structures are excessively long (for instance, a jetty extends several kilometers into the sea), it may be asked whether this article [Art. 8] could still be applied...

Since such cases are very rare, the Commission, while wishing to draw attention to this issue, did not consider it necessary to express its opinion." (ILC Yearbook, 1956, Vol. II, p. 270.) In the light of the above, at that time the ILC did not aim to define precisely the boundary beyond which a dyke, jetty or works would no longer constitute "an integral part of the harbour system".

The Court concludes from this that there are grounds for process on a case-by-case basis, and that the text of Article 11 of UNCLOS and the travaux préparatoires do not alleviate the possibility of interpreting restrictively the concept of harbour works so as to avoid or mitigate the problem of excessive length defined by the ILC. This may be particularly true where, as here, the issue is not to delimit the areas outside the territorial sea.

In general, the textual school of interpretation is limited to «literal» translation, and sometimes the historical background of the treaty is considered. Travaux preparatoires are applied if the text is unclear when parties to the treaty were not present at the negotiations in the event of ratification and could not assess all the consequences of the negotiations, and therefore their actions can be considered acceptable.

However, recently, in the "maritime" case Maritime Delimitation in the Indian Ocean (Somalia v. Kenya) (2017) the court also appealed to the travaux preparatoires in a seemingly paradoxical situation, when according to judge Mohamed Bennoun, the interpretative text is clear, not absurd, nor unreasonable in view of the purpose, and travaux as such simply is not present [10].

This complicated case concerned the establishment of external borders of the continental shelf for 200 nautical miles of the coastal states of the Federal Republic of Somalia and the Republic of Kenya in the Indian Ocean.

There was a controversial issue as to the jurisdiction of the Court. Since the terms for resolving the Commission on the Limits of the Continental Shelf (CLCS) under Art. $76 \S 8$ of the Convention on the Law of the Sea 
(UNCLOS) of 1982 came to an end in 2009, [23] Kenya and Somalia signed a «Memorandum of Understanding...» which spelled out the absence of objections of both states in the future regarding submission to the CLCS on delimitation, and which was duly registered and valid.

However, this Memorandum was developed by Norway's Ambassador H. W. Longwah as technical assistance to the African coastal states in response to UN GA's appeals (A / RES / 63/111 and A / RES / 64/71) and UNCLOS States Parties (SPLOS / 183), since, given the good experience in geology, geophysics and hydrography, it was difficult to implement technically. That is, the text was actually developed by a third party.

However, as noted by Vice-President Abdulqawi A. Yusuf, delimitation issues are purely legal and political issues that should be developed directly by two adjacent African states through negotiations and explicit agreements developed by legal experts, but this was not the case. Each party attributes certain legal consequences to the provisions of this agreement, when «there is practically no evidence of their actual contribution to the concept" [8].

In its judgment the Court noted the limited availability of preparatory materials and drew attention to the circumstances under which the Memorandum of Understanding was concluded [para 99] and referred to the previous experience of using the materials of the 1952 Santiago Conference as the travaux préparatoires in the case (Peru v. Chile) (2014) [14].

The Court recalls Chile's argument, based on Article 31, paragraph 2 (a), of the Vienna Convention on the Law of Treaties, that the protocol of the 1952 Conference is an "agreement relating to the treaty which was made between all the parties in connection with the conclusion of the treaty".

The Court considers that the minutes of the 1952 Conference briefly set out the discussions leading to the adoption of the 1952 Santiago Declaration, rather than record an agreement of the negotiating States. Therefor it is more appropriate to describe them as travaux préparatoires which are additional means of interpretation within the meaning of Article 32 of the Vienna Convention on the Law of Treaties.

In particular, the decision stated that the minutes of the conference summarized the discussions that led to the adoption of the 1952 Santiago Declaration, and did not fix the agreement of the negotiating states, that is, they are more appropriately characterized as travaux préparatoires, which are additional means of interpretation in the meaning of Article 32 of Vienna Convention [para 65]. However, as in other cases, 


\section{Karvatska Svitlana}

the court reviewed the relevant materials, that confirms the above interpretation of the 1952 Santiago Declaration [para 66] [5].

In terms of clarifying the intentions of the parties, the appeal to the travaux preparatoires by the Court would be ineffective, for example, in the case of the Interpretation of Peace Treaties with Bulgaria, Hungary and Romania of 30 March 1950, for the submitting of the advisory opinion on the interpretation of post-World War II peace treaties with Bulgaria, Romania and Hungary in 1947.

Let's say that the use of negotiation materials between the other parties to the treaty would be inappropriate since, during their conduct, representatives of delegations of the countries, who have lost the war, were deliberately avoided to the treaty-making process.

They were only involved when it was necessary to sign treaties, composed and represented by the winning states. In fact, the Court's decision was based on a general understanding of the circumstances under which the Treaties were signed.

The court understood that the countries, who have lost the war, signed «dictated» texts, and not ones agreed during negotiations with the defeated party. The positions of the victorious states regarding the post-war influence in the region have been largely aligned.

The use of the travaux preparatoires of the 1858 Treaty between Costa Rica and Nicaragua and other documents dealing with delimitation of the seaside (the exclusive economic zone and the continental shelf) in the Caribbean Sea and the Pacific (Maritime Delimitation in the Caribbean Sea and the Pacific (Costa Rica v. Nicaragua) and Land Boundary in the Northern Part of Isla Portillos (Costa Rica v. Nicaragua) was pretty successful.

In the 2015 decision, the Court stated «the lack of» detailed information «that left the geographical location of the area somewhat unclear about the configuration of the Isla Portilos coast «. This led to the Court's appeal to the historical context of the contractual consolidation of the formation of borders and the use of textual interpretation of treaties.

The Court has faced the question of the entry into force of the Treaty of 1858, which consolidated the land borders between the two states. It was confirmed by the Arbitration Decision of the President of the United States of Grover, Cleveland, 1887, in which 11 points of dubious interpretation were presented to Nicaragua in Costa Rica in the Agreement of 1886, which allowed to establish with certainty the «validity of the Treaty of 1858 », 
Art. II of which contained a description of the passage of the border, and in paragraph 3 (1) it was recorded that the «borderline between the two states on the Atlantic side» begins at the end of the Punta de Castile at the mouth of the San Juan de Nicaragua, as both they existed on April 15, 1858».

The Court also examined a historical context of the content of the «Limits of the Convention on the Limits of Demarcation» concluded between Costa Rica and Nicaragua in 1896 and the subsequent demarcation process made by US General Eduard Porter Alexander in 1897, whose reports have recorded the beginning of the area and «the coordinates of the starting point of the land boundary determined in relation to the center of Victoria Square in the old San Juan de Nicaragua (Greatauon) and other points on the earth».

\section{Intention of the parties to the treaty and textualism}

\section{as the main approaches used by the UN Court for interpretation}

The use of additional materials related to the interpretation of Art. 6 of the Memorandum of Understanding. After examining the circumstances of its conclusion, the Court in the previous decision reached the conclusion that it did not include the dispute settlement procedure concerning the maritime borders of the coastal states, and Art. 6 was interpreted strictly in the context of the purpose and object of the document that an agreement on the delimitation of their continental shelf would be achieved after receiving the recommendations of the Delimitation Commission and stated that there was no method for settling the dispute in the Memorandum, since it was not an agreement, and therefore, Kenya would not lose the opportunity to exercise jurisdiction of the Court [para 106].

But the focus and work of the Court was concentrated around the interpretation of the meaning of the expression «or otherwise» art. 6 of the Memorandum and ascertain whether it falls within the scope of the Kenyan reservation regarding its optional declaration, filed in accordance with Para. 2 of Art. 32 of the Statute in which the parties to the dispute have agreed or will agree to use another method or methods of settlement [4].

Judge Patrick Robinson [11], who in the dissenting opinion described in detail the interpretative motives of the Court when considering the case, especially from the point of view of Art. 282 of the United Nations Convention on the Law of the Sea, emphasized the importance of studying the preparatory materials for the «precise definition of the term 'or 


\section{Karvatska Svitlana}

otherwise', since the Court's understanding of this term essentially depends on preparatory work to clarify its meaning» [para 10] [11].

He explained the intention of the Court to interpret the meaning of this phrase in such a way that it included non-mandatory declarations of attitude, which reflect the content of paragraph 2 of Art. 32 without reservation [para 26] [11].

From the same angle, Marco Benatar and Erik Frank analyze the Court's interpretation of the interpretative task that the Court faced as a solution to the problem of disabling of a dispute settlement system under Art. 282 of the United Nations Convention on the Law of the Sea [2].

These are the optional declarations of the parties to the agreement as an additional procedure for the dispute settlement, apart from the main ones (appeal to the International Tribunal for the Law of the Sea (ITLOS), the UN Security Council, arbitration and special arbitration, which are the «default option» and governed by the special annex VII of the LOSC).

The default option means that (a) if the State party has not expressed an advantage, it is considered that it chose arbitration and (b) if the parties to the dispute did not accept the same procedure, a legal dispute may only be filed only with the arbitral tribunal.

That is, the States Parties to the Convention may agree on the conclusion of a general, regional, bilateral agreement «or otherwise», that their dispute about interpretation, at the request of one of the parties, will be transferred to the procedure leading to the mandatory decision, and this procedure used instead of the above-mentioned ones, unless the parties have agreed otherwise.

Therefore, the Court referred to the preparatory material of the Convention, namely the documents of the Third UN Conference on the Law of the Sea (UNCLOS) (1973-1982). At the time of the launch of UNCLOS, most of nonmandatory declarations provided reservation for an application to the ICJ, but the travaux preparatoires indicated that the States parties did not intend to exclude such declarations containing a caution. Consequently, the Court concludes that such cautions cannot prohibit the application of Art. 282.

In general, this case caused a lively discussion by scientists and practitioners of the issue of jurisdiction, since «for the first time, the Court faced the challenge of jurisdiction based on the Law of the Sea Convention (LOSC) (1982), and the way in which the Court ruled this argument has far-reaching consequences, since it casts a long shadow over the dispute settlement in the maritime law" [2]. 
In fact, Kenya raised objections to Part XV (LOSC), in which, in its opinion, a dispute settlement system is in place, which provides for the conclusion of the agreement on the method of settling the maritime border dispute with Somalia [2]. Therefore, Kenya has expressed its concern.

The political context of the case cannot be ignored either, since the tension and instability in the region and Somalia's refusal to implement the Memorandum of Understanding, which it considered invalid and unsuccessful [para 19], motivated the UN ICJ to help resolve the conflict situation from March 2010 to July 2015.

In the Court's practice there were cases where with the help of travaux preparatoires it was possible to change, correct the usual meaning of the term of the treaty, while strictly adhering to the requirement of Art. 31 consider the text in good faith and based on the «ordinary» meaning. This is possible in cases where this meaning does not reflect the intentions of the parties.

In particular, such intentions were to be established for the parties to the Anglo-German Treaty of July 1, 1890 in the case (Kasikilil/Sedudu Island (Botswana v. Namabiya) [12] (1999) on the delimitation of the border between the states.

The agreement concerned the division of spheres of influence in Africa between Great Britain and Germany, and the subject of the dispute was the Kasikilil/Sedudu Island, according to which there were differences in the texts of the parties to the treaty. For example, in the UK text it is recorded that the border passes around the Kasikili / Sedudu Island (the name consists of the names used in both countries) to 'the center of the main the channel' on the Chobe River».

The German text uses the word «Thalweg des Hauptlaufes» [para 46] [12]. The court defined the criteria for identifying the concepts of «main channel», «major channel», and determined that the usual meaning of the words has the term «main channel», and also expressed the view that for navigation the main issue is the visibility (or general appearance) and the configuration channel profile. Among the additional supporting documents, the Court also analyzed Eason Report (1912), Trollope-Redman correspondence (1947-1951), Joint Survey of 1985, Presence of Masubia on the Island - Relevunce offacts recorded, in absence of subsequent practice.

The practice of using travaux preparatoires after the entry into force of the VCLT has prompted discussion methods, possibilities and perspectives for their interpretation. The court used various means of interpretation, set out the 


\section{Karvatska Svitlana}

aims of the interpretation, planned its stages and explained the relationship between the parties at different stages of the contracting process.

However, Art. 31-32 of the Vienna Convention on the Law of Treaties do not allow travaux preparatoires to be properly operated and need to be improved. It is possible to accept proposals for the creation of a depository of travaux preparatoires, the obligations of States to transfer travaux preparatoires to the UN for a certain period. A decisive role and leadership in this process should play the ICJ.

However, the certification of certain types of travaux preparatoires and their quantitative restrictions raise doubts, although this really complicates and prolongs litigation. Most of the cases, where travaux preparatoiresare are used, relate to the establishment of sovereignty over the territories, the delineation of sea spaces, the continental shelf, etc., where the kind of involved documents cannot be foreseen.

The Court's analysis of the travaux preparatoires allowed it to state in the decision the following points: 1) the intentions of the parties provided for the use of these terms as synonyms; 2) and Botswana and Namibia have not expressed any objection to such an interpretation.

In particular, the Court noted that it was apparent from the travaux preparatoires of the agreement that the two contracting parties provided for the possibility of navigating along the Chobe River and had the intention to share this opportunity.

Although the parties to the Treaty of 1890 used the terms «thalweg» and «the center of the channel» as interchangeable, the first one reflects the general intention to navigate more accurately than the other. Thus, the Court used for the interpretation the analysis of the intentions of the parties to the agreement, as the main approach in combination with the textual one.

Noteworthy is the suggestion of $\mathrm{M}$. Rise concerning resolving of the issue of using travaux préparatoires by the International Court of Justice. The author makes a specific amendment to article 32 .

In particular, the first suggestion relates to the fact that the International Court of Justice is required to designate categories of travaux préparatoires which are subject to certification and form a formal preparation of the treaty.

The quantity of travaux préparatoires should be limited so that actual treatment does not lead to excessive loading of the litigation. At the same time, the number of prepared materials allows parties to communicate their views on issues related to the interpretation of the treaty. 
Another important idea is the suggestion that an international court should appoint a depository for travaux préparatoires.

Worth mentioning are the author's comments regarding the fact that, within one year after signature or accession, the signatories should collect and present for such certification and subsequent submission to the United Nations, such preparatory work, which consists of official travaux préparatoires.

Finally, it is an actual suggestion that the United Nations is required to establish and maintain appropriate means for the purposes of this article under the guidance of the International Court of Justice [19].

\section{Conclusions}

The most authoritative is the use of travaux preparatoires as additional materials by the UN International Court of Justice, because in this case they become the source of law. The main source of interpretation of treaties is the Vienna Convention, which contains the general rule of interpretation for all founding treaties of international organizations, however, the UN ICJ sometimes practices the interpretation of «treaties of a certain type», which are subject to a special approach.

The court used various means of interpretation, set out the aims of the interpretation, planned its stages and explained the relationship between the parties at different stages of the contracting process. However, Art. 31-32 of the Vienna Convention on the Law of Treaties do not allow travaux preparatoires to be properly operated and need to be improved.

One may accept proposals for the creation of a depository travaux preparatoires, for obliging the states to transfer them to the UN for a certain period, for a decisive role and leadership of the ICJ in this process, but the certification of certain types of travaux preparatoires and their quantitative restrictions raise doubts, although this really complicates and prolongs litigation. Most of the cases, where travaux preparatoiresare are used, relate to the establishment of sovereignty over the territories, the delineation of sea spaces, the continental shelf, etc., where the kind of involved documents cannot be foreseen.

The practice of travaux preparatoires requires, in the most of the cases, the combination of several interpretive approaches and extraordinary accuracy, logic, scrutiny, relevance in careful analysis and the explanation of additional materials to the texts of treaties. The appeal to the travaux preparatoires, 


\section{Karvatska Svitlana}

the by-product of which is the subjectivity of this practice, does not always find approval among the participants in the discussion, even among the judges of the ICJ who adhere to the rules of interpretation of Art. 31.

However, the more time it takes to adopt the most of the founding treaties of international organizations and apply the conventions by the Court, the greater is the necessity to turn to the evolutionary approach of interpretation and to find the true understanding of the provisions of the treaties by its participants with the help of travaux preparatoires, the use of which is not arbitrary in accordance with the requirements of the Vienna Convention. And even when the UN ICJ has to interpret third-party bilateral treaties that, without prior negotiations and developments, have been signed by independent states due to the lack of certain experience, it seeks to make maximum use of any opportunity to resolve the controversial issue and restore historic justice through the travaux preparatoires.

Noteworthy are suggestions concerning resolving of the issue of using travaux préparatoires by the International Court of Justice. They are related to the article 32. In particular, the first suggestion relates to the fact that the International Court of Justice is required to designate categories of travaux préparatoires which are subject to certification and form a formal preparation of the treaty.

The quantity of travaux préparatoires should be limited so that actual treatment does not lead to excessive loading of the litigation. At the same time, the number of prepared materials allows parties to communicate their views on issues related to the interpretation of the treaty.

Another important idea is the suggestion that an international court should appoint a depository for travaux préparatoires.

Another one bullet point is that within one year after signature or accession, the signatories should be collected and presented for such certification and subsequent submission to the United Nations, such preparatory work, which consists of official travaux préparatoires.

Finally, it is an actual suggestion that the United Nations is required to establish and maintain appropriate means for the purposes of this article under the guidance of the International Court of Justice.

We think that a problem controversial enough, which needs further scientific researches, of the International Court of Justice's appeal to travaux préparatoires should be covered systematically in order to simplify (improve, ease, optimize) the application process of travaux préparatoires. 
Whereas previously most of the issues examined by the International Court of Justice were territorial disputes, now the Court often examines cases concerning the interpretation and application of international treaties. Sometimes disputes about principles of environmental protection and even disputes about obligations about punishments of international crime.

Sometimes consideration of the case takes a lot of time. The issues examined by the Court are very important primarily for the participating States. Often these states ask for more than a year to prepare their written arguments and evidence. Observing the principle of equality, the Court shall grant equal time to both parties of the dispute. However, often it is not enough, because states are willing to respond substantially to the arguments of the other side. After an exchange of written evidence, the Court proceeds to debate. And only after that, the court retreats to make a decision. It usually takes from six to seven months.

A state cannot refuse to execute a court decision. As in this case, it will not fulfill its obligations under the UN Charter, according to which Court's decisions are mandatory. If one state does not fulfill its obligations under the Court's decision, the second one may apply to the UN Security Council.

The Court cannot advise the UN on whether to adopt or not international conventions or agreements. Its role is only to resolve disputes between states and render advisory opinions. The court does not initiate the creation of treaties or conventions. This must be handled by the state or the UN General assembly.

\section{References:}

1. Art. 32 Vienna Convention on the Law of Treaties (with annex). Concluded at Vienna on 23 May 1969. Retrieved from: https://treaties.un.org/pages/ ViewDetailsIII.aspx src $=$ TREATY \&mtdsg_no $=$ XXIII-1\&chapter $=23 \&$ Temp $=$ mtd sg3\&clang=

2. Benatar, Marco, \& Frank, Erik (2017). The ICJ's Preliminary Objection Judgment in Somalia v. Keniya: Causing Ripples in Law of the Sea Dispute Settlement?

3. Bossuyt, Marc J. (1987). Guide to the "Travaux Préparatoires" of the International Covenant on Civil and Political Rights. Dordrecht; Boston: M. Nijhoff.

4. Charter of the United Nations and Statute of the International Court of Justice. San Francisco, 1945. Retrieved from: https://treaties.un.org/doc/publication/ctc/ uncharter.pdf

5. Chile, Ecuador and Peru Declaration on the maritime zone. Signed at Santiago on 18 August 195. 2 No 14758. Retrieved from: https://treaties.un.org/ doc/Publication/UTS/volume\%201006/volume-1006-I-14758-English.pdf 


\section{Karvatska Svitlana}

6. Convention on the Territorial Sea and the Contiguous Zone, Geneva, 29 April 1958. Retrieved from: https://treaties.un.org/Pages/ViewDetails. aspx? $\mathrm{src}=\mathrm{IND \& mtdsg \_ no}=\mathrm{XXI}-1 \&$ chapter $=21 \&$ clang $=$ en

7. Craven, Matthew C. R. (1995). The International Covenant on Economic, Social, and Cultural Rights: A Perspective on its Development. Oxford: Clarendon Press.

8. Dissenting opinion of vice-president Yusuf (2016), p. 58.

9. Detrick, Sharon. (1992). The United Nations Convention on the Rights of the Child: A Guide to the "Travaux Préparatoires". Dordrecht; Boston: M. Nijhoff.

10. Dissenting opinion of judge Bennouna. (2017) P. 3. P. 65. Retrieved from: https://www.icj-cij.org/files/case-related/161/161-20170202-JUD-01-02-EN.pdf

11. Dissenting opinion of judge Robinson. (2017). Retrieved from: https://www.icj-cij.org/files/case-related/161/161-20170202-JUD-01-04-EN.pdf

12. Kasikilil/Sedudu Island (Botsicana v. Namibia), Judgrnent. I. C. J. Rerport. 1999. P. 1045. Retrieved from: https://www.icj-cij.org/files/caserelated/98/098-19991213-JUD-01-00-EN.pdf

13. Maritime delimitation in the Black Sea (Romania v. Ukraine) (2008).

14. Maritime Dispute (Peru v. Chile), Judgment, I. C. J. Reports 2014. P. 3. Retrieved from: https://www.icj-cij.org/files/case-related/137/137-20140127-JUD01-00-EN.pdf

15. Official Reports of the United Nations Conference on the Law of the Sea (1978). Vols. I to VII United Nations publication, Sales No. 58. Volume 4.

16. Pratter, Jonathan. À la Recherche des Travaux Préparatoires: An Approach to Researching the Drafting History of International Agreements. Retrieved from: http://www.nyulawglobal.org/globalex/Travaux_Preparatoires.html

17. Quayle, Peter. (September 2016). Treaties of a Particular Type : The ICJ's Interpretative Approach to the Constituent Instruments of International Organizations Leiden Journal of International Law. 29, 3, 853-877.

18. Rehof, Lars A. (1993). Guide to the Travaux Préparatoires of the United Nations Convention on the Elimination of all Forms of Discrimination Against Women. Dordrecht; Boston: M. Nijhoff.

19. Ris, Martin. (1991). Treaty Interpretation and ICJ Recourse to Travaux Préparatoires: Towards a Proposed Amendment of Articles 31 and 32 of the Vienna Convention on the Law of Treaties. Boston College International and Comparative Law Review. 14, 1, 12-1.

20. The Universal Declaration of Human Rights. The travaux préparatoires Volume I October 1946 to November 1947.

21. United Nations Conference on the Law of the Sea Geneva, Switzerland 24 February to 27 April 1958. Document: A/CONF.13/11 Method of Work and Procedures of the Conference: Report of the Secretary-General Extract from the Official Records of the United Nations Conference on the Law of the Sea, Volume I (Preparatory Documents). Retrieved from: http://legal.un.org/docs/?path=../ diplomaticconferences/1958 los/docs/english/vol_1/a_conf13 11.pdf\&lang=E

22. United Nations Conference on the Law of the Sea. Geneva, Switzerland 24 February to 27 April 1958 Document: A/CONF.13/18 Certain Legal Aspects Concerning the Delimitation of the Territorial Waters of Archipelagos Extract from the Official Records of the United Nations Conference on the Law of the 
Sea, Volume I (Preparatory Documents). Retrieved from: http://legal.un.org/ docs/?path=../diplomaticconferences/1958_los/docs/english/vol_1/a_conf13_18. pdf\&lang $=\mathrm{E}$.

23. United Nations Convention on the Law of the Sea (hereinafter "UNCLOS" or the "Convention") on 10 December 1982. Kenya and Somalia ratified UNCLOS on 2 March and 24 July 1989.

24. Weis, Paul. (1995). The Refugee Convention, 1951: The Travaux Préparatoires Analysed. Cambridge: Grotius Publications.

25. Wetzel, Ralf Günter \& Rauschning, Dietrich (1978). The Vienna Convention on the Law of Treaties: Travaux Préparatoires. Frankfurt: Metzner.

26. William, Schabas (2009). Genocide in International Law OC MRIA. Cambridge University Press. The Edinburgh Building, Cambridge CB2 8RU, UK Published. 